\title{
Buddhist Education Managment in Nava Nalanda Mahavihara University
}

\author{
Wanbing Shi \\ School of Humanity and Law \\ Northeastern University \\ Shenyang, Liaoning, China
}

\author{
Poonam Kumari \\ School of Humanity and Law \\ Northeastern University \\ Shenyang, Liaoning, China
}

\begin{abstract}
Purpose: The purpose of this paper is to find out about the Buddhist education management, Teaching and Research management, Faculties management, Administration and Financial management of the Nava Nalanda Mahavihara Buddhist University. Design/methodology/approach: Nava Nalanda Mahavihara Buddhist University has been offering courses and conducting research in the field of Buddhist Studies. It has made significant achievements in developing Buddhist Studies, yet there are still some issues that exist. Analyzing the issues and the effects of existing Buddhist higher education for management and development of the Nava Nalanda Mahavihra research University. Findings: This paper has analyzed the current situation of the Buddhist education management in the Nava Nalanda Mahavihara, how to management of Buddhist education, faculties, teaching and research, finance and administration. Originality/Value: A value of this paper to the developed of the Buddhist higher education and spared the teaching and research in all over world. According to me there was not any scholar's research on this topic.
\end{abstract}

Keywords-Nava Nalanda Mahavihara; Buddhist Education; Administration and Managements

\section{INTRODUCTION}

On 20 November 1951 Nava Nalanda Mahavihara University was founded by Ven. Jagdish Kashyap. The first president of the Republic of India Dr. Rajendra Prasad had under take idea of the Ven. Kashayp, and declared that the ancient seat of Buddhist higher education would be revived at the Nalanda. And thus Nava Nalanda Mahavihara was emanated a vision of established. Nava Nalanda Mahavihara University was developed as an institute, like that ancient Nalanda University. There were teachers and students lived together and devoting themselves for the Buddhist education, and higher academic aim to the promotion of Buddhist education and research in Pali language and literature, Buddhism by Tibetan, Sanskrit, Chinese, Mongolian, Japanese and another Asian Languages. [1]

The first time Nava Nalanda Mahavihara University was established a research institute by government of Bihar. It was called to only Magadha University of post graduate studies and research in Pali and Buddhist studies. On November 13, 2006 Nava Nalanda Mahavihara University accepted by University Grant Commission (UGC), The status of a Nava Nalanda Mahavihra Deemed to be University Ministry of Cultural, Government of Bihar. [2]

During the time of establishment of the Nava Nalanda Mahavihara Buddhist study and Pali language literature was not very popular in India. Because there were a very few Buddhist University in India, and a few students were study in Pali language and literature.

\section{DEPARTMENTS OF NAVA NALANDA MAHAVIHARA}

In the present time there are nine departments of studies in Nava Nalanda Mahavihara. The department of Pali, Buddhist Studies, Philosophy, Ancient History Culture \& Archaeology, Sanskrit, Hindi, English, Tibetan Studies, Chinese and Japanese. [3]

\section{MANAGEMENT OF BUDDHIST EDUCATION IN BUDDHIST DEPARTMENT}

Buddhist Studies Department is a most powerful part of the Nava Nalanda Mahavihra University. And the department of the Buddhist Studies has management of the Buddhist Education system, as like Study Program, Seat allocation and Reserved Seats for students, Eligibility Requirements for Admission, Curriculum, Teaching and Research, Faculties, Administration, Financial supports of Students and Rule of Regulation.

\section{A. Management of Study Program}

Buddhist Studies department has offered two courses for the students, Master Degree program and Ph.D. Degree Program. [4]

1) Master Degree Program: In Buddhist Department of the Nava Nalanda Mahavihara University has full time Master course of two years program in Buddhist studies. The program is divide into two parts, M.A part one and M.A. part two. Each M.A., parts can be completed by two semesters. The course is conducted by lectures, seminars and tutorials. The all syllabus papers is done by the class teachers between 40 to 50 Hours (approximately) during each semesters. There are four papers in the 1st, 2nd, 3rd, and 4th semesters, every paper carries 100 marks and out of which 25 
marks are allotted for internal easements. Total written examination papers carry 75 marks. [5]

a) Seat allocation for Students- In the Buddhist Studies department has only 40 seats for students in Master degree per years.

b) Eligibility Requirements for Admission- In admission to Master Degree candidate has to qualify in Bachelor's with 50\% marks recognized by any National and International University, and candidate must be passed in Entrance Test organized by Nava Nalanda Mahavihara University.

c) Curriculum- History of Pre-Buddhist India and the Origins of Buddhism, Pali Language and Literature, Buddhist Sanskrit Language \& Literature, Basic Buddhist Philosophical thought, History of Buddhism in India and Abroad, Buddhist Literature: Selected Reading I, Buddhist Heritage of Magadha, The origin and expansion of Buddhist Philosophical School, Buddhist Art and Architecture, Buddhist Literature: Selected Readings II, Buddhist Meditation \& Practices, Phases of Buddhism in India, Buddhist Literature: Selected Readings III, Buddhist Ethics and Engaged/ Contemporary. [5]

2) Ph.D. Degree Program: In Buddhist Department of the Nava Nalanda Mahavihara University has full time Research on Buddhist studies. The maximum time needed to complete a Ph.D. Degree in Buddhist Studies is four years. The program requires a course and research work. The minimum requirement of the course load should comprise four papers which can be finished by one semester. Every candidate should attend a minimum of $75 \%$ of the delivered number of lectures in each paper.The research Ccourse work is compulsory to all candidates. To enroll as a (PhD) candidate in Nava Nalanda Mahavihara University, the candidate should take a preregistration course work and research entrance test (RET) or NET/JRF/BET/Teacher Fellowship prepared by the University Grant Commission. If the candidate can't pass the test, he/she should have M.Phil with minimum $\mathrm{B}+$ Grade. In addition to this, the candidate should pass the paper on Research Methodology after taking admission to Ph.D. Program "Table I" "Table II". [5]

TABLE I. SEATS AllocAtion For PH.D. STUDENTS

\begin{tabular}{|l|l|l|}
\hline Professor & $\begin{array}{c}\text { Reader/Associate } \\
\text { Professor }\end{array}$ & Lecture/Assistant Professor \\
\hline 8 seats & 6 seats & 4 seats \\
\hline
\end{tabular}

a) Eligibility Requirement for Admission Management-In admission to Ph.D. Course who has passed Master degree recognized by any National and International University with $55 \%$ marks, and must be qualified in Research Entrance Test (RET) organized by Nava Nalanda Mahavihara, otherwise who has qualified in National Eligibility Test (NET), or Junior Research Fellowship (JRF) and State Level Eligibility Test (SLET) recognized by University Grant Commission(UGC) central and state government and M.Phil degree. In admission to Master Degree candidate has to qualify in Bachelor's with $50 \%$ marks recognized by any National and International University, and candidate must be passed in Entrance Test organized by Nava Nalanda Mahavihara University.

b) Research Direction- Origin of the Buddhism, Abhidhamma Pitaka, Hinayana and Mahayana Buddhism etc.

c) Teaching and Research Management- Academic activities, Teaching, Research, Seminar and Conference, Special Convocations, Publications and a maintenance or ongoing developed of library managements are main parts of the teaching system in this University. [4]

TABLE II. RESERVED SEATS FOR STUDENTS [4]

\begin{tabular}{|c|c|c|c|c|c|}
\hline $\begin{array}{c}\text { SC/ST/ } \\
\text { OBC } \\
(\boldsymbol{\%})\end{array}$ & $\begin{array}{c}\text { General } \\
\text { Cast } \\
(\boldsymbol{\%})\end{array}$ & $\begin{array}{c}\text { HP } \\
(\boldsymbol{\%})\end{array}$ & $\begin{array}{c}\text { Girls } \\
(\boldsymbol{\%})\end{array}$ & $\begin{array}{c}\text { Workers } \\
(\boldsymbol{\%})\end{array}$ & $\begin{array}{c}\text { Foreign } \\
\text { Students } \\
(\boldsymbol{\%})\end{array}$ \\
\hline $15 / 7.5 / 27$ & 7.5 & 3 & 15 & 10 & 15 \\
\hline \multicolumn{1}{|c|}{${ }^{\text {a. }}$ SC- Scheduled Castes } \\
${ }^{\text {b. }}$ ST- Scheduled Tribes \\
\end{tabular}

A. Management of Buddhist Department Structure "Fig. 1 "

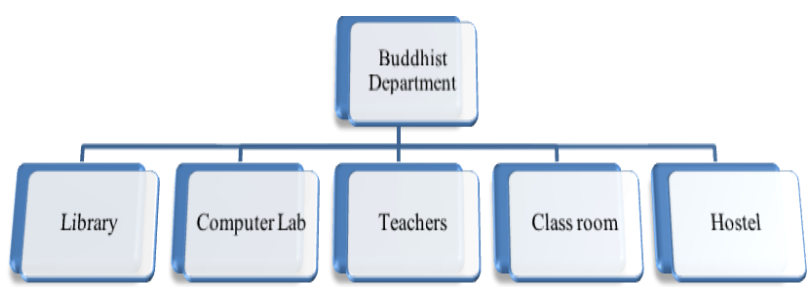

Fig. 1. Management of Buddhist Department Structure.

B. Administration of Nava Nalanda Mahavihara University "Fig. 2"

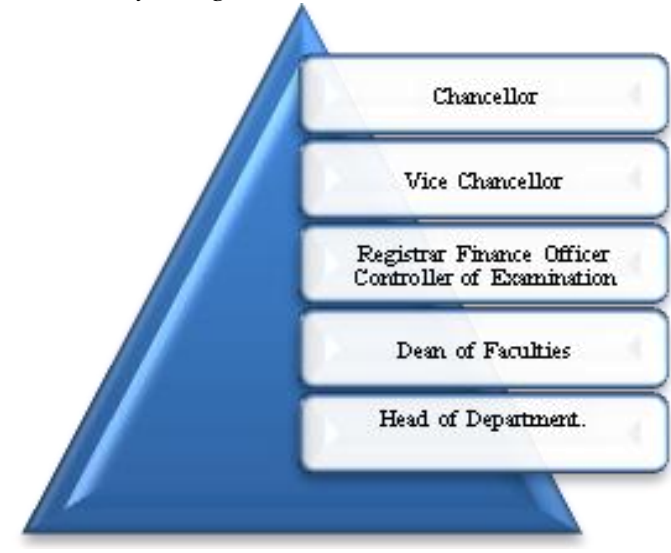

Fig. 2. Administration of Nava Nalanda Mahavihara University. 


\section{FINANCIAL AND FUndS MANAGEMENT}

\section{A. Funds}

Nava Nalanda Mahaviharathis University received funds by board, grants gifts, donations, benefaction, bequests and transfer. And Nava Nalanda Mahavihara received funds by board in any other manner and sources. [5]

\section{B. Financial}

The financial supports for the students is also management by the Nava Nalanda Mahavihara Nalanda Mahavihara, and this University provide every years Scholarship as an award in each class for ten excellent Indian and international Students. Full Scholarship is also available for International Buddhist students in the Bachelor Degree, Master Degree Ph.D. Degree, Diploma and Certificate Course. [5]

\section{RULES OF REGULATION}

There are three authorities or bodies of making rules and regulation. [5]

- Management of The University,

- Authorities Management of The Institutions

- Composition of the board of management.

\section{CONCLUSION}

It can be clearly seen that, Nava Nalanda Mahavihra University has made its contribution to the Buddhist higher education in the Asian Buddhist Countries. There was a very few Buddhist University in India after the ancient Nalanda Buddhist University. So Nava Nalanda Mahavihara University focus on the centre of higher education in Pali and Buddhism.

This University have some internal problem like faculty management, student's management and financial management. But Nava Nalanda Mahavihara University has self developing in the teaching, research and especially for the publication.

\section{REFERENCE}

[1] Si Esa Upasaka. "Nalanda Past and Present: Silver Jubilee Souvenir" [M]. Published, Nava Nalanda Mahavihara 1977, p no 22. Satkari Mookerjee." The Nava Nalanda Mahavihara Research Publication"[M]. Publication Nava Nalanda Mahavihara 1960.vol-2 p no 3.

[2] “Deemed University, Bihar". University Grant Commission (India). Retrieved 19 July 2016.

[3] http://www.nnm.ac.in/courses_\&_departments.html(Copyright 2014. Nava Nalanda Mahavihara, Bihar, India. All rights reserved)

[4] http://www.nnm.ac.in/Prospectus\%202016-17(3).pdf

[5] www.nnm.ac.in/Memorandum of Association Rules and Regulations NNM Nalanda.pdf 